\begin{tabular}{l|l|l|l|l|}
$\begin{array}{l}\text { Journal of } \\
\text { Endocrinology }\end{array}$ & G Helfer and Q-F Wu & $\begin{array}{l}\text { Chemerin in energy balance } \\
\text { regulation }\end{array}$ & $\mathbf{2 3 8 : 2}$ & R79-R94 \\
\hline
\end{tabular}

REVIEW

\title{
Chemerin: a multifaceted adipokine involved in metabolic disorders
}

\author{
Gisela Helfer ${ }^{1}$ and Qing-Feng Wu² \\ 1School of Chemistry and Biosciences, University of Bradford, Bradford, UK \\ 2State Key Laboratory of Molecular Development Biology, Institute of Genetics and Developmental Biology, Chinese Academy of Sciences, Beijing, China
}

Correspondence should be addressed to Q-F Wu: wu_qingfeng@genetics.ac.cn

\begin{abstract}
Metabolic syndrome is a global public health problem and predisposes individuals to obesity, diabetes and cardiovascular disease. Although the underlying mechanisms remain to be elucidated, accumulating evidence has uncovered a critical role of adipokines. Chemerin, encoded by the gene Rarres2, is a newly discovered adipokine involved in inflammation, adipogenesis, angiogenesis and energy metabolism. In humans, local and circulating levels of chemerin are positively correlated with BMI and obesity-related biomarkers. In this review, we discuss both peripheral and central roles of chemerin in regulating body metabolism. In general, chemerin is upregulated in obese and diabetic animals. Previous studies by gain or loss of function show an association of chemerin with adipogenesis, glucose homeostasis, food intake and body weight. In the brain, the hypothalamus integrates peripheral afferent signals including adipokines to regulate appetite and energy homeostasis. Chemerin increases food intake in seasonal animals by acting on hypothalamic stem cells, the tanycytes. In peripheral tissues, chemerin increases cell expansion, inflammation and angiogenesis in adipose tissue, collectively resulting in adiposity. While chemerin signalling enhances insulin secretion from pancreatic islets, contradictory results have been reported on how chemerin links to obesity and insulin resistance. Given the association of chemerin with obesity comorbidities in humans, advances in translational research targeting chemerin are expected to mitigate metabolic disorders. Together, the exciting findings gathered in the last decade clearly indicate a crucial multifaceted role for chemerin in the regulation of energy balance, making it a promising candidate for urgently needed pharmacological treatment strategies for obesity.
\end{abstract}

Key Words
- chemerin
CMKLR1
GPR1
- energy balance
glucose homeostasis
- whole body metabolism
- hypothalamus
- tanycytes

Journal of Endocrinology (2018) 238, R79-R94

\section{Introduction}

Adipokines, secreted by adipose tissue, are involved in the pathogenesis of metabolic syndrome (Lehr et al. 2012). Chemerin, encoded by the gene retinoic acid receptor responder 2 (Rarres2), also known as tazaroteneinduced gene 2 (TIG2), was recently identified as one of the adipokines with autocrine, paracrine and even endocrine roles in vivo (Rourke et al. 2013). Chemerin is an inflammatory chemokine and was originally discovered as a novel retinoic acid-responsive gene in psoriatic skin lesions, implying an immunomodulating role (Nagpal et al. 1997). Initially, chemerin was termed TIG2 because an increased expression was reported after treatment of skin raft cultures with tazarotone, a synthetic retinoid (Nagpal et al. 1997). It was further characterised as 
a retinoid-responsive gene and thereby called retinoic acid receptor responder 2 (Rarres2). Retinoic acid responsiveness of chemerin was later confirmed in various tissues and cells (Nagpal et al. 1997, Martensson et al. 2005, GonzalvoFeo et al. 2014, Helfer et al. 2016). Further studies revealed that chemerin was highly expressed in white adipose tissue (WAT), liver and lung while its receptor CMKLR1 is predominantly expressed in adipocyte and immune cells (Bozaoglu et al. 2007, Goralski et al. 2007). In mammalian cells, chemerin is initially synthesised as a 163 amino acid (aa) proprecursor. The N-terminal truncation of 20 aa signal peptide results in the release of inactive precursor (chemerin-S163) into extracellular niches or circulation system (Fig. 1A). The precursor requires further extracellular C-terminal cleavage at various sites to generate active and deactivated chemerin. For example, the proteolytic cleavage at its C-terminus by plasmin, elastase and cathepsin $\mathrm{G}$ activates chemerin and generates various isoforms (chemerin-K158, -S157 and -F156) with different affinity to CMKLR1 (Fig. 1B and C). Further cleavage of bioactive chemerin by chymase produces chemerin-F154 and terminates its activity (Mattern et al. 2014). Thus, the C-terminal proteolytic processing serves as a key regulatory mechanism to determine the local and systemic concentration of active chemerin. To date, eight serine proteases have been identified to C-terminally process chemerin and its precursor in vitro. These serine proteases are generally secreted into extracellular matrix or blood plasma to exert their biological effect (Mattern et al. 2014)

After secretion, chemerin precursor is processed by various extracellular proteases of the coagulation, fibrinolytic and inflammatory cascades, which are differentially expressed in a wide range of tissues and thereby produce distinct chemerin isoforms.
Although inert chemerin precursor is the dominant isoform in plasma from healthy humans, differential chemerin isoforms in human blood (chemerin-A155, -S157 and -K158), cerebrospinal fluid (chemerin-K158), ascites (chemerin-S157), hemofiltrate (chemerin-F154) and synovial fluid (chemerin-K158) under inflammatory conditions have been detected (Rourke et al. 2014). Results from mass spectrometry analysis indicate that bioactive chemerin generation takes place at early stages of inflammation (Wittamer et al. 2005). ELISAs using antibodies raised against C-terminal peptides have shown that Chemerin-K158 is the dominant isoform in the synovial fluid of patients with arthritis (Zhao et al. 2011). Further analysis reveals that the fraction of bioactive chemerin is much higher in the inflammatory cerebrospinal fluid and synovial fluid from patients than the plasma from healthy volunteers (Zhao et al. 2011). In the adipose tissue of patients with obesity, chemerin isoforms display a different profile from plasma, with minimal chemerin precursor and significant levels of bioactive chemerin-S157 (Chang et al. 2016). These results suggest that complex chemerin processing occurs in vivo, especially during inflammation. Mass spectrometry analysis is required to determine the profile of chemerin isoforms in other parenchymal tissues such as liver and lung.

Chemerin has been shown to display various roles in the pathogenesis of inflammatory and metabolic disease in multiple organs such as adipose tissue, lung, skin, cardiovascular system, reproductive tract, digestive tract, skeleton and joints. The biological function of chemerin as pro- or anti-inflammatory modulators remains controversial. At the onset of inflammatory reaction, polymorphonuclear cells are firstly recruited to the damaged sites, where they promote the generation
A
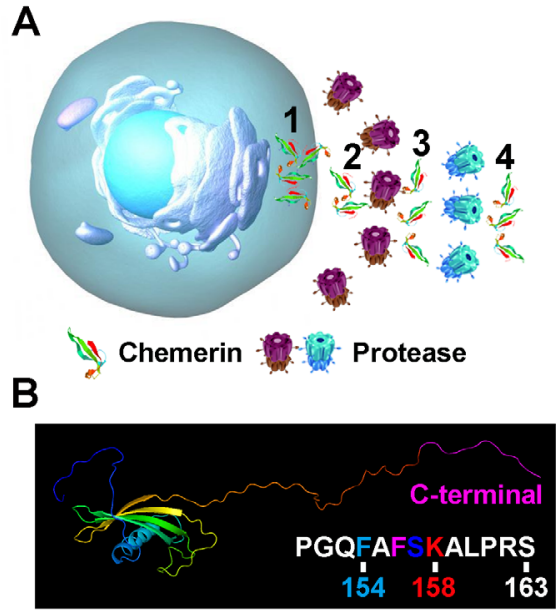

C

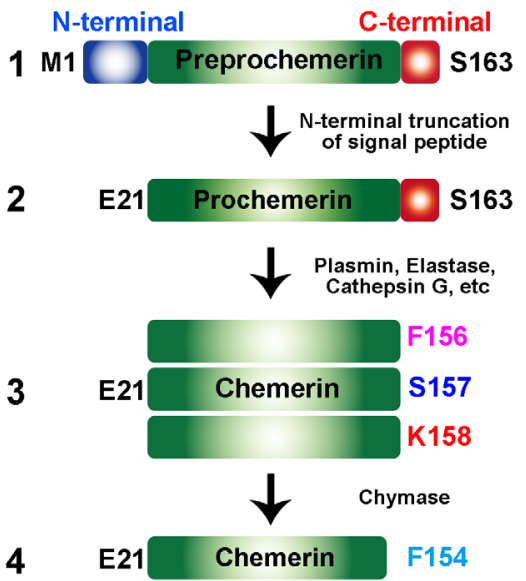

Figure 1

Processing of prochemerin. (A) The scheme describes the release of preprochemerin (1), proteolysis of prochemerin (2) into bioactive chemerin (3) and transformation of active isoform into deactivated chemerin (4). (B) The predicted 3D structure of chemerin from RaptorX structure prediction server. (C) The processing of prochemerin by various proteases. http://joe.endocrinology-journals.org https://doi.org/10.1530/JOE-18-0174
(C) 2018 The authors Published by Bioscientifica Ltd. Printed in Great Britain

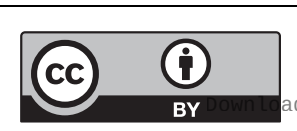

This work is licensed under a Creative Commons Attribution 4.0 Unported License. ed from Bioscientifica.com at 04/26/2023 10:58:23AM 
of bioactive chemerin by releasing proteases including elastase and cathepsin G into the milieu (Wittamer et al. 2003, 2005). Subsequently, chemerin functions to enhance the chemotaxis of immature dendritic cells and macrophages, bridging innate and adaptive immunity for the initiation of immune response. In contrast, chemerin treatment reduces the recruitment of neutrophil and macrophages to the inflammatory sites and the expression of proinflammatory cytokine (Cash et al. 2008, Luangsay et al. 2009). These studies suggest that chemerin acts as either a proinflammatory or anti-inflammatory modulator depending on the biological systems. A fundamental switch in our understanding of chemerin's function occurred in 2007 when chemerin was found to be highly expressed in WAT (Goralski et al. 2007). Subsequent studies revealed that chemerin acts on its receptor CMKLR1 to affect adipogenesis, angiogenesis and inflammation in adipose tissue. Beyond the lipid metabolism, chemerin also influences the dysregulation of glucose metabolism. Supporting the important roles of chemerin in systemic lipid and glucose metabolism, accumulating clinical data indicate that local and/or circulating chemerin levels are increased in patients with obesity, diabetes and cardiovascular disease (Perumalsamy et al. 2017). Given the scope of this review, we are focusing exclusively on the role of chemerin in regulating metabolism.

\section{Chemerin and its receptors}

As a chemoattractant protein, chemerin was first identified as the natural ligand for the G-protein-coupled receptor CMKLR1, also known as ChemR23 (Meder et al. 2003, Wittamer et al. 2003). Later, owing to a high sequence identity, chemerin was also recognised as the ligand for another G protein-coupled receptor GPR1 (Barnea et al. 2008, Southern et al. 2013, Rourke et al. 2014). The third chemerin receptor chemokine (C-C motif) receptor-like 2 (Ccrl2) was identified in experiments based on binding assays (Zabel et al. 2008). Recently, De Henau et al. generated cell lines expressing each individual chemerin receptor and compared their binding and signalling properties separately of cellular context. Chemerin binds to both CMKLR1 and GPR1 with similar affinity, but lower affinity to CCRL2 (De Henau et al. 2016).

Chemerin receptor signalling has been reviewed in detail recently (Mattern et al. 2014, Kennedy \& Davenport 2018) and therefore we only provide a short summary here before we discuss the role of chemerin and its receptors in energy balance regulation. Chemerin receptors display cell-specific expression profiles, thus making a comparison of receptor activation in the same tissue difficult (Kennedy \& Davenport 2018). CMKLR1 expression is wide-spread in different organs and tissues. It is expressed in the adaptive immune system, with high level of transcripts detected in macrophages, natural killer cells, immature dendritic cells and leucocytes (Samson et al. 1998, Wittamer et al. 2003, Vermi et al. 2005, Parolini et al. 2007). Additionally, it has been detected in the cardiovascular system (including smooth muscle cells, endothelial cells and cardiomyocytes), the reproductive system (such as Leydig cells) and the skin (Li et al. 2014, Banas et al. 2015, Kennedy et al. 2016). In line with chemerin's role as an adipokine, CMKLR1 is expressed in adipocytes, with higher levels in white compared to brown adipose tissue (BAT) (Goralski et al. 2007). In the brain, CMKLR1 is found in microglia of the hippocampus as well as ependymal cells and tanycytes lining the third ventricle of the hypothalamus (Guo et al. 2012, Helfer et al. 2016). CMKLR1 is a $G_{i / o}$-protein-coupled receptor that signals through mitogen-activated protein kinase (MAPK), extracellular signal-regulated kinases (ERK) and phosphatidylinositol 3 kinase (PI3K)-AKT pathways to regulate biological functions such as angiogenesis and inflammation (Wittamer et al. 2003, Goralski et al. 2007, Sell et al. 2009, De Henau et al. 2016).

GPR1 is predominantly expressed in central nervous system, such as glioblastoma cells, brainderived fibroblast-like cells lines and microglia although expression was also reported in skin cells, white adipocytes, Leydig cells and granulosa cells (Edinger $e t$ al. 1998, Shimizu et al. 1999, Reverchon et al. 2012, Li et al. 2014, Banas et al. 2015). Limited studies have investigated signalling transduction properties of GPR1 upon activation of chemerin. As with CMKLR1, GPR1 activates ERK1/2-MAPK pathways (Rourke et al. 2015, De Henau et al. 2016). Furthermore, binding of chemerin to CMKLR1 and GPR1 promotes RhoA/ROCK-dependent pathways (Rourke et al. 2015).

Unlike CMKLR1 and GPR1, the binding of chemerin to CCRL2 does not induce downstream signalling pathways, calcium mobilisation or ligand internalisation, and it is therefore designated as an atypical, silent or nonsignalling chemokine receptor. CCRL2 seems to have the ability to amplify local chemerin concentration for CMKLR1 interaction (Zabel et al. 2008, De Henau et al. 2016). http://joe.endocrinology-journals.org https://doi.org/10.1530/JOE-18-0174
(C) 2018 The authors Published by Bioscientifica Ltd. Printed in Great Britain

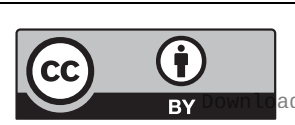

This work is licensed under a Creative Commons Attribution 4.0 Unported License. ded from Bioscientifica.com at 04/26/2023 10:58:23AM via free access 
The role of chemerin in energy balance regulation and obesity

\section{Effect on whole body metabolism}

After the discovery of leptin, adipokines have been increasingly found to have many effects on biological functions including blood pressure, homeostasis, adipogenesis and glucose metabolism linking adipokines to the metabolic syndrome. Several studies have suggested that the adipokine chemerin plays a crucial role in adipogenesis, and this has been implicated in the control of adipose tissue in regard to the regulation of glucose homeostasis and the development of obesity.

In general, contradictory results have been reported on what role chemerin plays in whole body metabolism and how it links to obesity and insulin resistance. Initially, studies in humans indicated that chemerin gene expression and circulating levels are positively correlated with increased BMI and obesity-related biomarkers (Bozaoglu et al. 2007, 2009, Sell et al. 2009, Chakaroun et al. 2012). In support, plasma chemerin levels are increased in diet-induced obese mice and reduced by overnight fasting. This effect is independent of the strain of mice (FVB and C57BL/6) used (Wargent et al. 2015). In contrast, there was no change of plasma chemerin levels in NMRI mice on a high-fat or cafeteria diet (Hansen et al. 2014). This discrepancy might be explained by different strains of mice being more susceptible to diet-induced obesity than others. Plasma chemerin levels were raised in genetically obese (ob/ob) mice (Ernst et al. 2010), whereas leptin receptor-deficient mice ( $\mathrm{db} / \mathrm{db}$ mice) had decreased levels of serum chemerin concentration and displayed an increase in insulin signalling (Takahashi et al. 2008). In rats maintained on a restricted diet, a decrease in the level of chemerin (Rarres2) mRNA in the WAT was associated with a decrease of serum chemerin concentration. When these rats were re-fed after diet restriction, both chemerin expression in WAT and serum chemerin concentration were upregulated (Stelmanska et al. 2013). Surprisingly, intraperitoneal injections of chemerin into rats resulted in a lower body weight (Brunetti et al. 2014). This seems to contradict the notion that raised plasma chemerin levels promote obesity. Our study using chemerin injections directly into the brain suggested that there is a bimodal response on body weight and food intake. Acute intracerebroventricular bolus injection of chemerin decreased body weight while chronic chemerin infusion increased body weight (Helfer et al. 2016). Thus, chemerin might exert different biological actions depending on the timeframe investigated.
Given that most studies report increased chemerin levels with increased body weight, a long-term proinflammatory effect might link it to insulin resistance in obesity. While intraperitoneal injections of chemerin into normal mice had no effect on glucose tolerance, there was increased glucose intolerance in ob/ob mice and $\mathrm{db} / \mathrm{db}$ mice (Ernst et al. 2010). Further indications linking chemerin with glucose homeostasis were provided by studies using mice lacking the GPR1 receptor. Gpr1knockout mice on a high-fat diet showed increased glucose intolerance compared to wild-type mice, but displayed no change in body weight, body composition and energy expenditure (Rourke et al. 2014) (explained in detail later).

Similarly, studies using Cmkrl1-knockout mice have reported inconsistent metabolic phenotypes. Cmklr1knockout mice have reduced food intake and body weight compared to wild-type mice when fed on either a low- or a high-fat diet (Ernst et al. 2012) but other studies have found no or little effect on body composition and glucose homeostasis (Rouger et al. 2013, Gruben et al. 2014). The differences reported might have been due to age and sex of the mice and different lengths and diets used in these studies. Recently, Wargent et al. have attempted to clarify the situation and found that male and female Cmklr1knockout mice on a high-fat diet have mildly increased body fat and impaired glucose homeostasis, although this is age dependent (Wargent et al. 2015). Thus, it is unclear whether raised chemerin levels promote obesity and more studies are needed to provide a definite answer.

\section{Effect on the brain}

Chemerin and its receptors are localised in distinct brain regions indicating a potential central role. In mice and rats, chemerin (Rarres2) mRNA is expressed in the hypothalamus (Miranda-Angulo et al. 2014, Helfer et al. 2016). In rats, Cmklr1 transcript was found in the prefrontal cortex, hippocampus, cerebellum and hypothalamus (Guo et al. 2012, Helfer et al. 2016). Both CMKLR1 and GPR1 are highly expressed in the mouse brain, but the tissue specificity has not been identified among different brain regions (Rourke et al. 2014). Although it has been reported that hypothalamic nuclei express Gpr1 in particularly high levels, Gpr1 mRNA were not found to be expressed in the rat hypothalamus using in situ hybridisation (Helfer et al. 2016). In GPR1 knockout mice, chemerin (Rarres2) mRNA expression is increased in the hypothalamus, whereas CMKLR1 expression is simultaneously decreased in the cortex and hypothalamus (Fig. 2A) (Rourke et al. 2014).

This work is licensed under a Creative Commons
Attribution 4.0 Unported License.


Given the important role of chemerin in energy balance regulation and obesity, surprisingly little is known about its expression and function in the hypothalamus, the key area of energy balance regulation. In the brain, the hypothalamus is critical in sensing and integrating peripheral signals such as adipokines (Coll \& Yeo 2013). In the hypothalamus of rats, chemerin and Cmklr1 (but not Gpr1) transcripts were localised in the ependymal cells and tanycytes, specialised glial cells lining the third ventricle and extending into the arcuate nucleus, hypothalamic areas closely associated with homeostatic appetite regulation. The third chemerin receptor CCRL2 was also found in the same hypothalamic loci, possibly increasing the local chemerin signal (Helfer et al. 2016). In contrast, in mice, chemerin is predominantly expressed in ependymal cells but not in the tanycytes (MirandaAngulo et al. 2014). The observation that chemerin is not expressed uniformly in the hypothalamus might suggest that it plays different roles in different locations (Fig. 2A); however, a potential species-specific expression pattern needs to be confirmed in further studies.

An initial link between chemerin and appetite and body weight regulation in the hypothalamus was identified in genome-wide expression analysis (Ross et al. 2011). Further investigations identified chemerin as downstream target of retinoic acid signalling in the hypothalamus in photoperiod-sensitive F344 rats (Fig. 2B). Intracerebroventricular injections of all-trans retionic acid into the third ventricle of F344 rats increased chemerin mRNA expression in ependymal cells and tanycytes lining the third ventricle (Helfer et al. 2016). Photoperiod-sensitive mammals can be stimulated to make marked physiological changes in body weight and food intake status simply by changing photoperiod (daylength); thus, they are used as a natural model of obesity (Ebling 2014). While laboratory rats are generally not responsive to photoperiod, the F344 rat is one of the few rat strains that retained its photoperiod sensitivity and undergoes pronounced cycles of weight gain and weight loss under different photoperiod conditions (Tavolaro et al. 2015). In the hypothalamus of F344 rats, chemerin is strongly regulated by photoperiodic changes. Furthermore, intracerebroventricular administration of chemerin into F344 rats alters food intake and body weight with associated changes in hypothalamic neuropeptides involved in feeding and growth (Fig. 2C). However, in

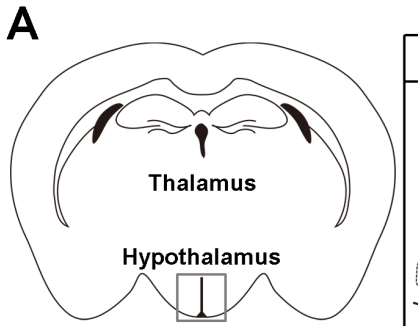

B

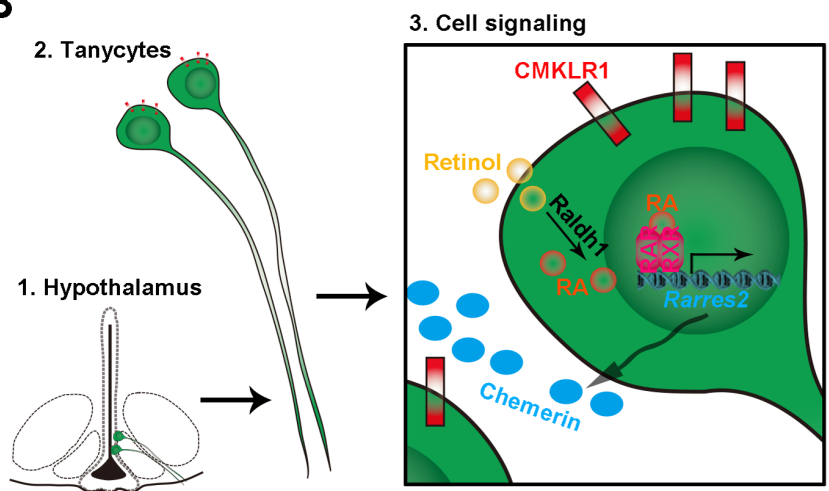

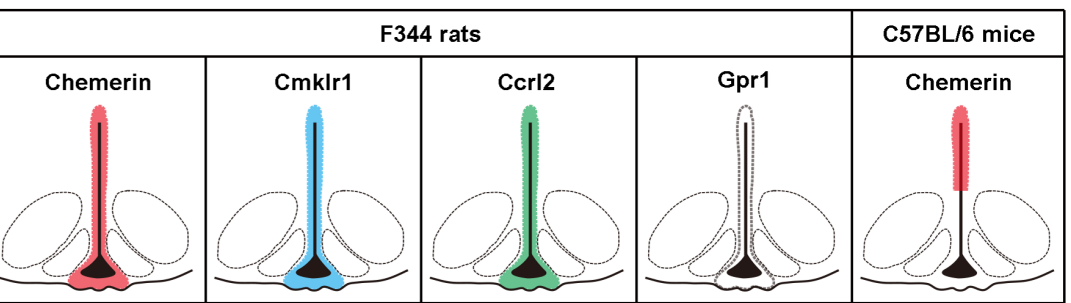

C

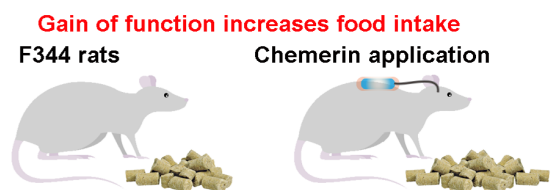

Loss of function reduces food intake

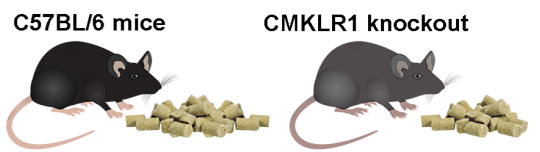

Figure 2

The expression, signalling and function of chemerin in the hypothalamus. (A) Chemerin, CmkIr1, Ccrl2 but not Gpr1 are expressed in the tanycytes and ependymal cells lining the third ventricle of the hypothalamus of F344 rats (Helfer et al. 2016). In C57BL/6 mice, chemerin expression is restricted to ependymal cells (Miranda-Angulo et al. 2014). (B) In tanycytes, chemerin is downstream of retinoic acid signalling. Retinol enters the tanycytes where it is synthesised to retinoic acid (RA). RA enters the nucleus and binding to its receptors RAR and RXR leads to transcription of Rarres2, which is translated into chemerin. Chemerin binds to its receptor CMKLR1 and activates its downstream signalling pathway in an autocrine or paracrine manner. (C) In general, long-term application of chemerin increases food intake and loss of function reduces food intake, although contradictory results have been reported.

http://joe.endocrinology-journals.org https://doi.org/10.1530/JOE-18-0174
C 2018 The authors Published by Bioscientifica Ltd. Printed in Great Britain

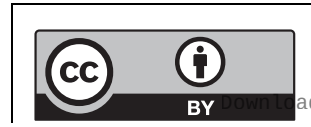

This work is licensed under a Creative Commons Attribution 4.0 Unported License. 
F344 rats, this response is transient and not sustained over long term (Helfer et al. 2016). To investigate the role that chemerin plays, not only in mediating a photoperiodic response, but also as a gateway for a feedback signal from the periphery to the hypothamus, the results in the F344 rat need to be confirmed in non-seasonal animals. To this date, a study in Sprague-Dawley rats has reported that acute injection of chemerin into the arcuate nucleus of the hypothalamus has no effect on food intake and body weight nor the expression of appetite-regulating neuropeptides. This negative result may be explained by the dose of chemerin and the injection site used in this study (Brunetti et al. 2011). Later, the same authors used peripheral chemerin injections and showed a reduction in food intake and body weight, but this seemed to have only a minor effect on hypothalamic neuropeptide expression (Brunetti et al. 2014).

While these studies showed seemingly contradictory responses due to different routes, mode of delivery and doses used, the results indicate that chemerin might not act directly through known neuroendocrine appetiteregulating pathways to exert its effects. This idea is supported by the finding that mice lacking CMKLR1 show reduced food intake and body weight but no changes in hypothalamic neuropeptides (Ernst et al. 2012). An exciting further possibility is that chemerin might play a role in hypothalamic cellular remodelling. Central chemerin administration (acute and chronic) increases expression of vimentin, an intermediate filament protein, which is used as a marker for visualising cells of glial origin such as ependymal cells and tanycytes. Additionally, longterm central chemerin infusion results in morphological changes to the hypothalamus by increasing vimentin immunolabelling of tanycytes (Helfer et al. 2016). These results suggest that chemerin plays a pivotal part in hypothalamic remodelling driving long-term changes in body weight and food intake regulation. Together, the studies highlight a critical role for chemerin in the neuroendocrine control of energy metabolism. Further studies are necessary to understand how the hypothalamus integrates chemerin signal and will provide new insights into the physiological basis of appetite regulation.

It is interesting to note that independent of a neuroendocrine role of chemerin, Cmklr1 mRNA has recently been shown to be upregulated in Alzheimer patients and in mice, it was identified as a receptor for amyloid- $\beta$ peptides suggesting a potential role of chemerin in the progression of Alzheimer's disease (Peng et al. 2015). Additionally, CMKLR1 expression in the hippocampus and prefrontal cortex of rats was recently linked with depression (Guo et al. 2012), possibly through activation by resolvins (Deyama et al. 2018) adding yet another level of complexity to the biological role of chemerin. Thus chemerin-CMKLR1 interaction in the brain remains a fascinating avenue for further research.

\section{Effect on adiposity}

Adiposity is a condition of morbid overweight. Without using body weight, adiposity indexes that include the waist circumference indicate the amount of WAT, a strong predictor of metabolic disorder in humans (Bergman et al. 2011). The white fat tissue per se releases a plethora of adipokines including chemerin to affect adipose tissue homeostasis, adipocyte metabolism and inflammation in fat tissue (Fig. 3). Chemerin and Cmklr1 are expressed at high levels in WAT but only in low levels in BAT (Goralski et al. 2007). BAT is associated with thermogenesis; hence, this would suggest that chemerin exerts its effect on weight by regulating adipogenesis rather than thermogenesis. However, recently, it has been shown that loss of CMKLR1 suppresses the expression of thermogenesis-related genes in WAT and BAT (Huang et al. 2016). Due to its capability to produce heat instead of ATP resulting in weight loss, BAT has been identified as a potential target for treatment of obesity. Retinoic acid is a key player in the regulation of thermogenesis of BAT (Okla et al. 2017). Given that chemerin is downstream of retinoic acid signalling, this raises the intriguing possibility that chemerin could promote BAT activity and/or browning of WAT.

\section{Targeting adipocytes}

Adiposity is featured by an excessive expansion of WAT that relies on an increase in adipocyte size (hypertrophic obesity) and adipocyte number (hyperplastic obesity) (Sun et al. 2011). During the differentiation of human preadipocytes into adipocytes, the expression of both chemerin and CMKLR1 is dramatically increased (Roh et al. 2007). The activation of chemerin-CMKLR1 axis facilitates the proliferation and differentiation of preadipocytes by inducing the AKT-mTOR and ERK signalling cascade (Jiang et al. 2018). Interestingly, chemerin-CMKLR1 signalling, regulated by peroxisome proliferator-activated receptor $\gamma(\operatorname{PPAR} \gamma)$, predisposes the differentiation of bone marrow mesenchymal stem cells (BMSCs) into adipocytes rather than osteoblasts (Muruganandan et al. 2011, 2017). Inactivation of chemerin-CMKLR1 signalling by genetic manipulation or neutralisation with antibodies shifts the adipogenic clonal expansion of BMSCs to osteoblastogenic differentiation 


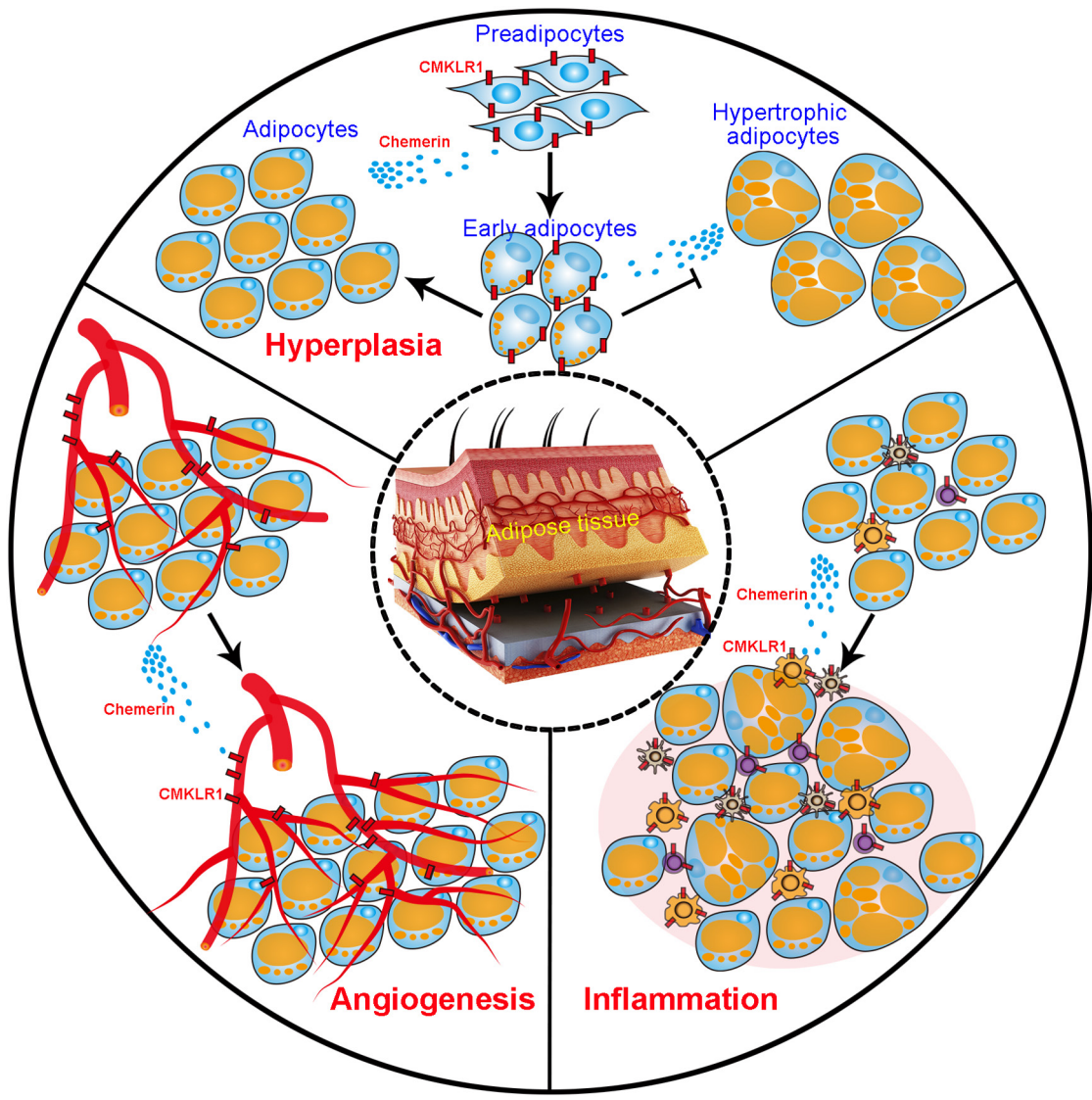

Figure 3

The multidimensional effect of chemerin on adiposity. Multiple roles of chemerin in regulating inflammation, hyperplasia and angiogenesis in white adipose tissue are summarised.
(Muruganandan et al. 2011, 2017). Chemerin treatment also alters the fate of myoblast cells from myogenesis to adipogenesis (Li et al. 2015). Consistent with these studies, disruption of Cmklr1 gene in vivo reduces the food intake, body mass and fat deposition of mice (Ernst et al. 2012). In contrast, another more recent study showed that Cmklr1-knockout mice display mild obesity but normal adipocyte differentiation (Rouger et al. 2013). It is found that the number of adipocytes is not changed in the Cmklr1-null mice, but there is an increase in the lipid storage in each of adipocytes. Unexpectedly, the differentiation of preadipocytes into adipocytes in vitro is not altered by loss of CMKLR1 (Rouger et al. 2013). The conflicting data confound our understanding of the role of chemerin in regulating adipogenesis. It is worthwhile to determine whether sex, diet, genetic background and sanitary status of animals influence the body weight and fat deposition of Cmklr1-knockout mice, as well as whether the cell type and the culture condition affect the preadipocyte differentiation.

\section{Targeting endothelial cells}

Adipose tissue consists of adipocytes and vascular endothelial cells, which provide blood supply for the growth of adipocytes (Rupnick et al. 2002, Liu \& Meydani 2003, Cutchins et al. 2012). Remodelling of existing vascular networks and formation of new blood vessels via angiogenesis are required to supply more nutrients and oxygen to the expanding adipose tissue mass (Lijnen 2008). CMKLR1 is expressed in human endothelial cells and is upregulated by proinflammatory cytokines (Kaur et al. 2010). Chemerin activates the key angiogenic pathways through PI3K-AKT and MAPK-ERK signalling and induces angiogenesis in vitro by promoting the proliferation, differentiation, capillary tube formation and migration of endothelial cells (Kaur et al. 2010). The effect of chemerinmediated activation of MAPK-ERK signalling cascade is dose dependent and the application of MEK1 inhibitor abolishes chemerin-induced angiogenesis (Bozaoglu et al. 2010, Kaur et al. 2010, Neves et al. 2015). The high expression of chemerin has recently been associated with upregulation of vascular endothelial growth factor (VEGF) and tumour angiogenesis (Wang et al. 2014, Lin et al. 2016). Concomitant with the enhancement of preadipocyte differentiation, chemerin overexpression upregulates VEGF that promotes vascular endothelial cell proliferation, differentiation and angiogenesis in the cultured cells. Moreover, the vascular intensity 
in the fat pad is increased by the overexpression of chemerin (Jiang et al. 2018), suggesting that chemerin boosts angiogenic potential of fat tissues. A genomewide association study in human population implies that serum chemerin level is highly heritable and significantly associated with single nucleotide polymorphism in EIDL3 gene, which has been known to regulate angiogenesis (Bozaoglu et al. 2010). Thus, the reciprocal interaction between adipocytes and vascular endothelial cells may form a positive feedback loop promoting adipogenesis and obesity.

\section{Targeting immune cells}

It has been widely accepted that increased adiposity is associated with chronic low-grade systemic inflammation (metainflammation) (Tam et al. 2010, Mraz \& Haluzik 2014, Catrysse \& van Loo 2017). Beyond adipocytes and endothelial cells, adipose tissue contains a number of immune cells (Weisberg et al. 2003, DiSpirito \& Mathis 2015). CMKLR1 is expressed in numerous immune cells that accumulate in the obese adipose tissue, including plasmacytoid dendritic cells, myeloid dendritic cells, macrophages and natural killer cells (Zabel et al. 2005, 2006, Parolini et al. 2007). Chemerin was first identified to promote the chemotaxis of immature dendritic cells and macrophages (Wittamer et al. 2003, 2005). A recent study confirmed that chemerin recruits circulating dendritic cells into visceral adipose tissue, wherein adipocyte-derived HMGB1 protein activates TLR9 in the dendritic cells and induces the secretion of type I interferons. Subsequently, interferons in turn ignite the proinflammatory response of macrophages (Ghosh et al. 2016). The initiation of local and systemic inflammation by the adipocyteimmunocyte crosstalk significantly contributes to insulin resistance and obesity. However, whether and how the inflammation exacerbates adiposity remains unclear. Several studies support a role for macrophages in regulating adipocyte hyperplasia (Keophiphath et al. 2009, Zhang et al. 2013, Brown et al. 2014). One study reported that human preadipocytes exposed to the conditioned medium from activated macrophages exhibited profound remodelling of extracellular matrix (Keophiphath et al. 2009). The alteration of extracellular microenvironment significantly increases the proliferation and migration of preadipocytes, which expands the pool of adipocyte progenitors and could increase the adipose tissue in obesity. Another observation is that the macrophages, accumulated around the foci of dying adipocytes, promotes recruitment, proliferation and differentiation of adipocyte progenitors by secreting osteopontin (Lee et al.
2013). Macrophages have been shown to form crownlike structure around dying adipocyte after high-fat diet feeding (Kim et al. 2014). Further experiments are required to determine whether macrophages drive the high-fatinduced hyperplasia of adipocyte. Together, these studies suggest that chemerin may exacerbate the adiposity by recruiting immune cells to the adipose tissue.

\section{Effect on glucose metabolism}

Type 2 diabetes mellitus (T2DM) is a metabolic disorder featured by insulin resistance ensued by elevated blood glucose (hyperglycaemia). Increased serum chemerin that occurs with obesity is highly correlated with the development of T2DM in humans (Roman et al. 2012). Although there is consensus that chemerin regulates glucose homeostasis, its role in regulating glucose tolerance remains unclear owing to the contradictory results derived from various in vivo and in vitro studies. Given that the insulin signalling pathway is the hub to maintain glucose homeostasis by increasing the uptake of glucose into fat and muscle and reducing the production of glucose in the liver, here, we summarise the function of chemerin in regulating insulin secretion and sensitivity (Table 1).

\section{Targeting insulin secretion}

Both glucose-stimulated insulin secretion from pancreas and insulin-stimulated glucose uptake in peripheral tissues contribute to the proper regulation of glucose tolerance. Chemerin and its receptor CMKLR1 are also expressed in the $\beta$ cells of the pancreas, implying their role in modulating insulin secretion (Takahashi et al. 2011). Indeed, chemerin and CMKLR1-knockout mice display reduced glucose-stimulated insulin release, while the gainof-function study using chemerin transgenic mice shows enhanced insulin secretion in glucose tolerance tests (Takahashi et al. 2011, Ernst et al. 2012). Mechanistically, loss of chemerin in mice downregulates the expression of transcription factor MAFA and its downstream target gene GLUT2, which serves as a sensor and transporter for glucose in pancreatic $\beta$ cells and thereby promotes insulin secretion (Takahashi et al. 2011). It is thus speculated that declined expression of GLUT2 in the chemerindeficient $\beta$ cells underlies the impaired glucose-stimulated insulin secretion. Interestingly, chronic overexpression of chemerin in low-density lipoprotein receptor (LDLR)knockout mice does not alter the circulating level of insulin (Becker et al. 2010), suggesting the existence of a crosstalk between GLUT2 and LDLR in $\beta$ cells (Thedrez et al. 2016).

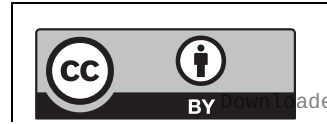

This work is licensed under a Creative Commons Attribution 4.0 Unported License. 
Table 1 Summary of the role of chemerin in glucose metabolism.

\begin{tabular}{|c|c|c|c|c|c|c|}
\hline \multirow[b]{2}{*}{ Experimental models } & \multicolumn{5}{|c|}{ Phenotype } & \multirow[b]{2}{*}{ Reference } \\
\hline & Glucose level & $\begin{array}{l}\text { Fasting } \\
\text { insulin }\end{array}$ & $\begin{array}{l}\text { Glucose-stimulated } \\
\text { insulin release }\end{array}$ & $\begin{array}{l}\text { Insulin-stimulated } \\
\text { glucose uptake }\end{array}$ & $\begin{array}{l}\text { Glucose } \\
\text { production }\end{array}$ & \\
\hline $\begin{array}{l}\text { Chemerin-knockout } \\
\text { mice }\end{array}$ & $\begin{array}{l}\text { Normal fasting } \\
\text { glucose; impaired } \\
\text { glucose tolerance }\end{array}$ & N.A. & Reduced & $\begin{array}{l}\text { Enhanced muscle } \\
\text { glucose uptake }\end{array}$ & $\begin{array}{l}\text { Normal basal } \\
\text { glucose } \\
\text { production, } \\
\text { increased } \\
\text { clamped } \\
\text { glucose } \\
\text { production }\end{array}$ & $\begin{array}{l}\text { Takahashi et al. } \\
\text { (2011) }\end{array}$ \\
\hline $\begin{array}{l}\text { Chemerin } \\
\text { overexpression } \\
\text { transgenic mice }\end{array}$ & $\begin{array}{l}\text { Improved glucose } \\
\text { tolerance }\end{array}$ & N.A. & Enhanced & N.A. & N.A. & $\begin{array}{l}\text { Takahashi et al. } \\
\text { (2011) }\end{array}$ \\
\hline $\begin{array}{l}\text { CMKLR1-knockout } \\
\text { mice }\end{array}$ & $\begin{array}{l}\text { Reduced fasting } \\
\text { glucose under HFD } \\
\text { condition; } \\
\text { impaired glucose } \\
\text { tolerance }\end{array}$ & $\begin{array}{l}\text { Lower } \\
\text { under } \\
\text { HFD } \\
\text { condition }\end{array}$ & Reduced & $\begin{array}{l}\text { Reduced WAT and } \\
\text { muscle glucose } \\
\text { uptake }\end{array}$ & N.A. & Ernst et al. (2012) \\
\hline $\begin{array}{l}\text { CMKLR1-knockout } \\
\text { mice }\end{array}$ & $\begin{array}{l}\text { Normal fasting } \\
\text { glucose and } \\
\text { normal glucose } \\
\text { tolerance under } \\
\text { HFD condition }\end{array}$ & Normal & N.A. & N.A. & N.A. & $\begin{array}{l}\text { Gruben et al. } \\
(2014)\end{array}$ \\
\hline GPR1-knockout mice & $\begin{array}{l}\text { Normal fasting } \\
\text { glucose; impaired } \\
\text { glucose tolerance } \\
\text { under HFD } \\
\text { condition }\end{array}$ & $\begin{array}{l}\text { Lower } \\
\text { under } \\
\text { HFD } \\
\text { condition }\end{array}$ & Reduced & Normal & Increased & $\begin{array}{l}\text { Rourke et al. } \\
\text { (2014) }\end{array}$ \\
\hline $\begin{array}{l}\text { Chemerin application } \\
\text { in mice }\end{array}$ & $\begin{array}{l}\text { Exacerbated glucose } \\
\text { intolerance in } \\
\text { ob/ob, } \\
\text { db/db and HFD } \\
\text { mice }\end{array}$ & N.A. & $\begin{array}{l}\text { Reduced in in } \\
\text { ob/ob, db/db } \\
\text { and HFD mice }\end{array}$ & $\begin{array}{l}\text { Reduced liver } \\
\text { glucose uptake in } \\
\text { db/db mice }\end{array}$ & N.A. & Ernst et al. (2010) \\
\hline $\begin{array}{l}\text { Chemerin application } \\
\text { in 3T3-L1 cells }\end{array}$ & N.A. & N.A & N.A. & Increased & N.A. & $\begin{array}{l}\text { Takahashi et al. } \\
\text { (2008) }\end{array}$ \\
\hline $\begin{array}{l}\text { Chemerin application } \\
\text { in 3T3-L1 cells }\end{array}$ & N.A. & N.A & N.A. & Reduced & N.A. & $\begin{array}{l}\text { Kralisch et al. } \\
\text { (2009) }\end{array}$ \\
\hline $\begin{array}{l}\text { Chemerin application } \\
\text { in skeletal muscle } \\
\text { cells }\end{array}$ & N.A. & N.A & N.A. & Reduced & N.A. & Sell et al. (2009) \\
\hline
\end{tabular}

The second receptor for chemerin, GPR1, binds chemerin with a similar affinity to CMKLR1 (De Henau et al. 2016). The GPR1-deficient mice display not only a mild reduction in glucose-stimulated insulin release but also a significant lower level of fasting serum insulin under high-fat dietary condition (Rourke et al. 2014). Although previous studies provide some insight into the role of chemerin-CMKLR1 or chemerin-GPR1 axis in coordinating glucose-induced insulin secretion, the precise mechanisms are still not clear.

\section{Targeting insulin resistance}

Chemerin has also been reported to regulate insulin sensitivity and glucose uptake (Table 1). It is conflicting that in vitro studies using 3T3-L1 adipocytes provide data for both promotive (Takahashi et al. 2008) and inhibitory (Kralisch et al. 2009) effects of chemerin

$$
\text { http://joe.endocrinology-journals.org }
$$

on glucose uptake. The different dosages, durations of chemerin treatment and culture conditions may cause the discrepancy. In the skeletal muscle cells, chemerin administration inhibits the insulin-stimulated glucose uptake and increases the phosphorylation of insulin receptor substrate 1 (Sell et al. 2009). Another in vivo study shows that chemerin application exacerbates the glucose intolerance in different mouse models of obesity or diabetes but has no effect on normal lean mice. This study shows that chemerin, upregulated in obesity and diabetes, specifically reduces the glucose uptake by liver but not adipose tissue or skeletal muscle (Ernst et al. 2010).

Notably, all of chemerin, CMKLR1 and GPR1 mutant mice display glucose intolerance. Chemerinknockout mice exhibit impaired insulin sensitivity in adipose tissue and liver, resulting in the elevated hepatic glucose production, reduced glucose uptake by fat and

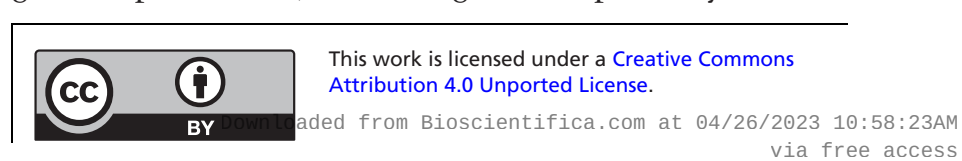


increased blood glucose level (Takahashi et al. 2011). Genetic deletion of CMKLR1 in mice leads to reduced glucose uptake by adipose tissue and skeletal muscle but not liver (Ernst et al. 2012). Under high-fat diet feeding, loss of CMKLR1 exacerbates the glucose intolerance, increases insulin level and enhances insulin resistance in mice (Huang et al. 2016). Consistently, heterozygous and homozygous Gpr1-knockout mice fed with highfat diet develop severe glucose intolerance but exhibit reduced glucose-stimulated insulin level (Rourke et al. 2014). Overall, the blood glucose levels are elevated in these mutant mice. However, the underlying mechanisms remain to be explored. In contradiction to these results, another study demonstrated that CMKLR1 deficiency in mice did not change body weight, food intake, serum lipid level or insulin resistance (Gruben et al. 2014). Thus, the role of chemerin signalling in glucose intolerance needs to be validated.

\section{Targeting hepatic gluconeogenesis}

Gluconeogenesis, a metabolic pathway resulting in the generation of glucose from non-carbohydrate carbon substrates, takes place mainly in liver. Despite that the liver weight and histology are not changed in chemerinnull mice, the main regulators of gluconeogenesis including glucose-6-phosphatase, phosphoenolpyruvate carboxylase and transcriptional coactivatior PGC$1 \alpha$ are upregulated by genetic ablation of chemerin (Takahashi et al. 2011). As a result, the clamp hepatic glucose production is significantly increased in chemerinnull mice, suggesting that loss of chemerin impairs insulin suppression of hepatic glucose generation.

Further analyses in the Cmklr1-knockout mice reveal that loss of chemerin signalling reduces the mRNA expression of proinflammatory cytokines TNF $\alpha$ and IL-1 $\beta$ in the liver, regardless of age or diet (Ernst et al. 2012, Gruben et al. 2014). Interestingly, CMKLR1 loss alters immune cell infiltration in the livers of mice fed with lowfat but not high-fat diet. Consequently, CMKLR1 deficiency protects against hepatic steatosis in the mice fed with low-fat diet. These results imply that chemerin-CMKLR1 signalling is indeed involved in hepatic inflammation but does not change liver histology. Whether CMKLR1 loss impairs gluconeogenesis requires further study.

\section{The association of chemerin with metabolic disease in humans}

Elevated circulating chemerin is a significant factor for metabolic syndrome. It is hypothesised that chemerin is multidimensionally involved in the pathogenesis of metabolic syndrome by regulating metainflammation, adipocyte plasticity and glucose metabolism in humans. The correlation between chemerin and obesity/diabetes/ hypertension seems to be well established. Chemerin has also been associated with many other diseases, including psoriasis, cardiovascular disease and cancer (Fig. 4), reviewed in detail elsewhere (Booth et al. 2015, Chiricozzi et al. 2016, İnci et al. 2016).

\section{Obesity}

A number of human data indicate that systemic chemerin is elevated in obesity. There is a significant and positive correlation between chemerin level and BMI, waist-hip ratio, waist circumference or visceral adipose tissue mass (Bozaoglu et al. 2007, Chakaroun et al. 2012, Landgraf et al. 2012, Shin et al. 2012), implying that visceral fat tissue is the primary source for circulating chemerin. A further study shows that the release of chemerin from adipose tissue explants from obese individuals is higher than that in normalweight controls, and the amount of secretion is linearly correlated with BMI, waist-hip ratio and fat cell volume (Sell et al. 2009). Consistent with these studies, systemic chemerin is decreased correspondingly in obese patients who underwent weight loss by diet intervention or bariatric surgery (Sell et al. 2010, Chakaroun et al. 2012). Interestingly, weight loss by exercise decreases systemic chemerin levels even further, implying that chemerin is a strong predictor for change in insulin resistance in obese adults (Chakaroun et al. 2012, Khoo et al. 2015, Faramarzi et al. 2016). A recent study indicates that exercise alone in elderly, independent of weight loss, has a beneficial effect on chemerin levels (Kim et al. 2018).

Although the CMKLR1 mRNA level in fat tissue is not changed by obesity, the local RARRES2 mRNA expression in visceral and subcutaneous adipose tissue is significantly increased in obese individuals (Chakaroun et al. 2012). It is chemerin expression in omental but not subcutaneous fat tissue that contributes to the elevated systemic chemerin. With the development of ELISAs targeting the four different isoforms of chemerin, it is found that more C-terminal processing of chemerin occurs in adipose tissue of obese patients, resulting in the higher level of bioactive chemerin in local tissue and circulating system (Chang et al. 2016). Obese patients are at increased risk of developing numerous comorbid conditions, and increased chemerin levels have been linked to many of these diseases (Fig. 4).

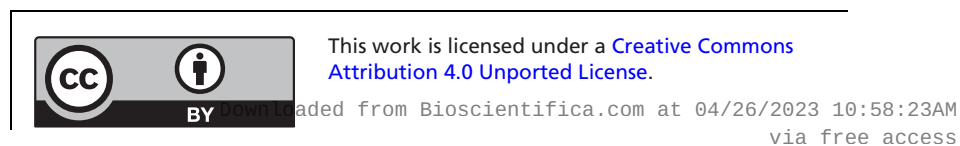




\begin{tabular}{l|l|l|l|l|}
$\begin{array}{l}\text { Journal of } \\
\text { Endocrinology }\end{array}$ & G Helfer and Q-F Wu & $\begin{array}{l}\text { Chemerin in energy balance } \\
\text { regulation }\end{array}$ & $\mathbf{2 3 8 : 2}$ & $\mathbf{R 8 9}$ \\
\hline
\end{tabular}

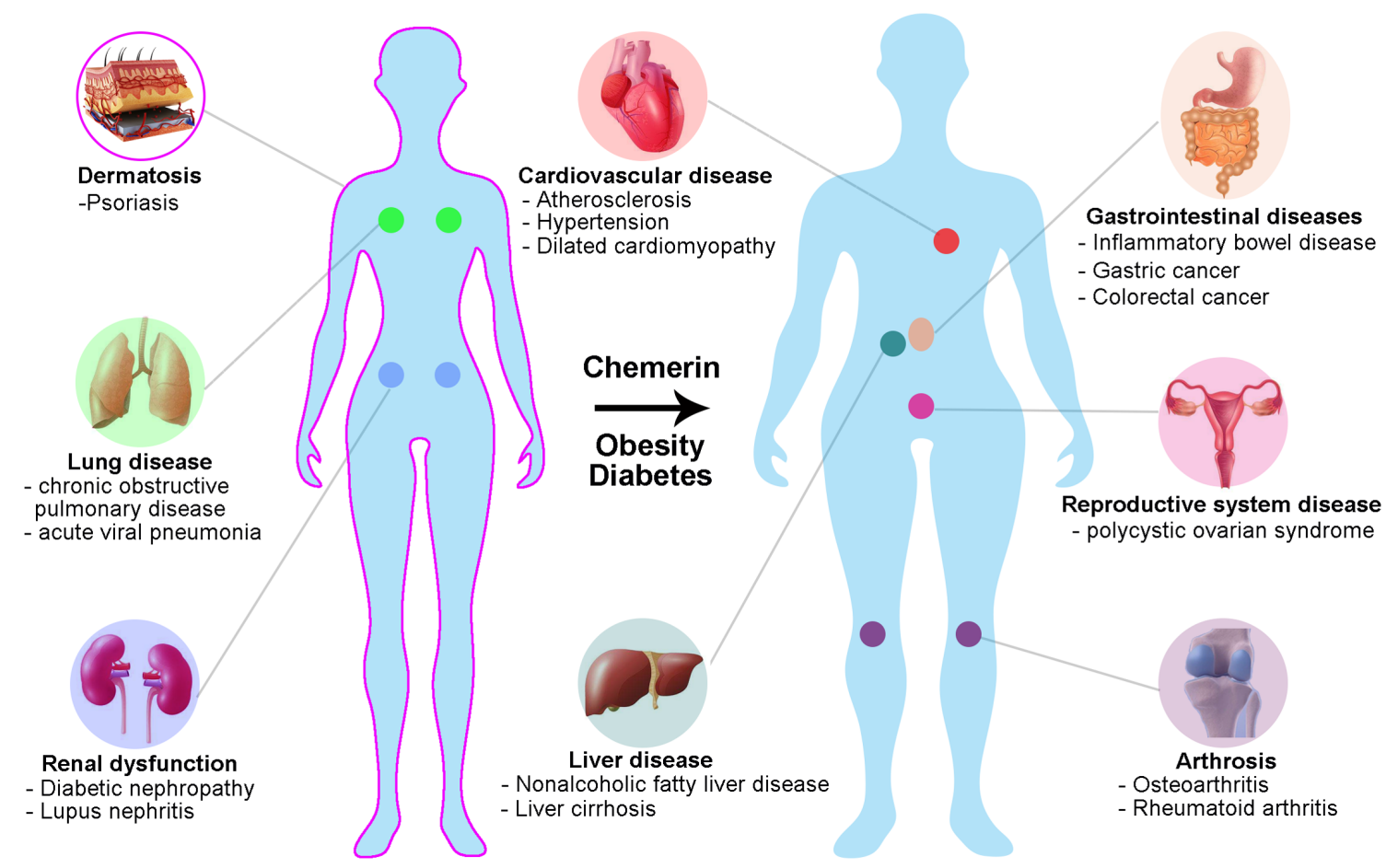

\section{Figure 4}

The involvement of chemerin in human diseases. Chemerin is associated with metabolic processes and inflammation and thus its dysregulation plays a critical role in human pathophysiology. Chemerin has hitherto been linked with obesity, diabetes, hypertension, psoriasis, lung disease, renal dysfunction, arthrosis and cardiovascular, gastrointestinal and reproductive disease.

\section{Diabetes}

Recently, novel adipokines such as vaspin, omentin, retinal-binding protein-4, fibroblast growth factor 21, adipocyte fatty acid-binding protein and dipeptidyl peptidase 4 were found to associate with insulin resistance and T2DB in humans (Bergmann \& Sypniewska 2013). A collection of clinical studies have also investigated the correlation between chemerin levels and diabetes. While systemic chemerin in patients with T2DM was significantly elevated compared to normal-weight controls in the Caucasian population (Weigert et al. 2010), it was not changed or even reduced in Asian T2DM patients without other metabolic complications (Yang et al. 2010, Takahashi et al. 2013). Importantly, a prospective study shows that the elevation of systemic chemerin precedes the onset of T2DM (Bobbert et al. 2015), suggesting that chemerin could serve as a biomarker for early diagnosis of T2DM. Regardless of racial difference, linear regression analyses further reveal a cross-sectional correlation between systemic chemerin in T2DM patients and age, BMI, waist-hip ratio, triglyceride, HOMA-IR, HbA1c, 2-h plasma glucose or blood pressure (Weigert et al. 2010, Yang et al. 2010, Bobbert et al. 2015). The elevation of systemic and local chemerin in adipose tissue is strikingly exacerbated in obese individuals with T2DM (Bozaoglu et al. 2009, Sell et al. 2010, Chakaroun et al. 2012). However, the correlation between circulating chemerin and gestational diabetes mellitus has hitherto remained very controversial (Bozaoglu et al. 2009, Hare et al. 2014, Guelfi et al. 2017, Yang et al. 2017). Together, the systemic and local chemerin seems to be upregulated in T2DM patients, especially those with metabolic syndrome.

\section{Hypertension}

Hypertension is recognised as an important constituent of metabolic syndrome. Patients with hypertension have significantly higher levels of serum chemerin (Yang et al. 2010, Gu et al. 2014). Despite the potential association of chemerin with metabolic characteristics, high chemerin level can serve as an independent predictor of hypertension after adjustment for metabolic risk factors in humans (Gu et al. 2014). As abnormal vascular smooth muscle contractility is a major cause of hypertension, chemerin may act on CMKLR1 to mediate vasoconstriction or promote the proliferation of vascular smooth muscle cells (Kunimoto et al. 2015, Kennedy et al. 2016). A recent study further reveals that chemerin functions through $G_{i}$ 
proteins to activate L-type $\mathrm{Ca}^{2+}$ channel and elicits a dosedependent calcium influx in vascular smooth muscle cells, which underlies chemerin-induced vasocontraction and hypertension (Ferland et al. 2017). A pyridine derivative, Y27632, was found to target a Rho-associated protein kinase (ROCK) and suppress ROCK-mediated $\mathrm{Ca}^{2+}$ sensitisation (Uehata et al. 1997). Coinciding with the finding that chemerin signals through RhoA/ROCK pathway, ROCK inhibitor Y27632 abolishes chemerininduced calcium influx and isometric contraction of smooth muscle cells (Rourke et al. 2015, Ferland et al. 2017). Therefore, upregulation of serum chemerin could result in the vasocontraction via ROCK activation and $\mathrm{Ca}^{2+}$ sensitisation in vascular smooth muscle cells.

\section{Conclusion}

Adipokines have recently emerged as potential regulators of appetite and energy homeostasis through endocrine/ systemic action in the brain. Circulating levels of adipokines are known to change with increased adiposity and are therefore recognised as contributing factor to the metabolic changes that are seen in obesity and lead to the development of T2DM. One mechanism by which adipokines contribute to T2DM is through inflammationmediatedinsulin resistance. As an inflammatory chemokine and adipokine, chemerin has been hypothesised as a link between obesity and the development of T2DM (Ernst \& Sinal 2010). Targeting chemerin-CMKLR1 signalling may therefore hold therapeutic potential to improve insulin signalling in T2DM.

\section{Potential therapeutic role in obesity}

Sequence analysis revealed a PPAR $\gamma$ response element within the chemerin (RARRES2) promoter (Muruganandan et al. 2011); thus, insulin-sensitising drugs that activate PPAR $\gamma$ might be beneficial for the treatment of obesity and T2DM. In support, in normal and leptin-deficient ob/ob mice, the PPAR $\gamma$ agonist rosiglitazone increased the expression of chemerin transcript in adipose tissue and raised plasma chemerin level (Muruganandan et al. 2011, Wargent et al. 2015). However, a human study using antidiabetic drugs reported the opposite effect. Pioglitazone and metformin decreased plasma chemerin levels in patients with T2DM (Esteghamati et al. 2014). It is therefore not clear whether an agonist or antagonist of chemerin action might be useful for the treatment of T2DM and the contribution of chemerin to the pathology of obesity and T2DM remains elusive.

\section{Future research}

Collectively, these studies illustrate the complexity of chemerin function. Research on this topic is still in its infancy and considerably more work is required to clarify the mechanisms by which chemerin contributes to obesity and associated diseases. Nevertheless, these findings have now opened the field to future studies investigating its precise biological function. Specifically, the pharmacology and signalling properties of chemerin receptors have not been characterised in the hypothalamus. Given the importance of the hypothalamus in sensing and integrating peripheral signals, studies into hypothalamic chemerin signalling might help explain some of the contradictory results that have been obtained. Furthermore, it is important to understand whether chemerin exerts a proor anti-inflammatory response or if the effect is indeed bimodal in different biological systems.

In summary, the exciting findings gathered in the last decade clearly highlight an important role for chemerin in the regulation of energy balance and makes it a promising candidate for urgently needed pharmacological treatment strategies for obesity.

\section{Declaration of interest}

The authors declare that there is no conflict of interest that could be perceived as prejudicing the impartiality of this review.

\section{Funding}

This work is supported by funding from the Hundred-Talent Program (Chinese Academy of Sciences), National Natural Science Foundation of China (31771131) and Strategic Priority Research Program of the Chinese Academy of Sciences (XDA16020100) to Q F W.

\section{References}

Banas M, Zegar A, Kwitniewski M, Zabieglo K, Marczynska J, KapinskaMrowiecka M, LaJevic M, Zabel BA \& Cichy J 2015 The expression and regulation of chemerin in the epidermis. PLOS ONE 10 e0117830. (https://doi.org/10.1371/journal.pone.0117830)

Barnea G, Strapps W, Herrada G, Berman Y, Ong J, Kloss B, Axel R \& Lee KJ 2008 The genetic design of signaling cascades to record receptor activation. PNAS 105 64-69. (https://doi.org/10.1073/ pnas.0710487105)

Becker M, Rabe K, Lebherz C, Zugwurst J, Goeke B, Parhofer KG, Lehrke M \& Broedl UC 2010 Expression of human chemerin induces insulin resistance in the skeletal muscle but does not affect weight, lipid levels, and atherosclerosis in LDL receptor knockout mice on high-fat diet. Diabetes 59 2898-2903. (https://doi.org/10.2337/db10-0362)

Bergmann K \& Sypniewska G 2013 Diabetes as a complication of adipose tissue dysfunction. Is there a role for potential new biomarkers? Clinical Chemistry and Laboratory Medicine 51 177-185. (https://doi. org/10.1515/cclm-2012-0490) 
Bergman RN, Stefanovski D, Buchanan TA, Sumner AE, Reynolds JC, Sebring NG, Xiang AH \& Watanabe RM 2011 A better index of body adiposity. Obesity 19 1083-1089. (https://doi.org/10.1038/ oby.2011.38)

Bobbert T, Schwarz F, Fischer-Rosinsky A, Maurer L, Mohlig M, Pfeiffer AF, Mai K \& Spranger J 2015 Chemerin and prediction of diabetes mellitus type 2. Clinical Endocrinology 82 838-843. (https://doi. org/10.1111/cen.12707)

Booth A, Magnuson A, Fouts J \& Foster M 2015 Adipose tissue, obesity and adipokines: role in cancer promotion. Hormone Molecular Biology and Clinical Investigation 21 57-74. (https://doi.org/10.1515/hmbci2014-0037)

Bozaoglu K, Bolton K, McMillan J, Zimmet P, Jowett J, Collier G, Walder K \& Segal D 2007 Chemerin is a novel adipokine associated with obesity and metabolic syndrome. Endocrinology 148 4687-4694. (https://doi. org/10.1210/en.2007-0175)

Bozaoglu K, Segal D, Shields KA, Cummings N, Curran JE, Comuzzie AG, Mahaney MC, Rainwater DL, VandeBerg JL, MacCluer JW,et al. 2009 Chemerin is associated with metabolic syndrome phenotypes in a Mexican-American population. Journal of Clinical Endocrinology and Metabolism 94 3085-3088. (https://doi.org/10.1210/jc.2008-1833)

Bozaoglu K, Curran JE, Stocker CJ, Zaibi MS, Segal D, Konstantopoulos N, Morrison S, Carless M, Dyer TD, Cole SA, et al. 2010 Chemerin, a novel adipokine in the regulation of angiogenesis. Journal of Clinical Endocrinology and Metabolism 95 2476-2485. (https://doi.org/10.1210/ jc.2010-0042)

Brown KD, Maqsood S, Huang JY, Pan Y, Harkcom W, Li W, Sauve A, Verdin E \& Jaffrey SR 2014 Activation of SIRT3 by the NAD(+) precursor nicotinamide riboside protects from noise-induced hearing loss. Cell Metabolism 20 1059-1068. (https://doi.org/10.1016/j. cmet.2014.11.003)

Brunetti L, Di Nisio C, Recinella L, Chiavaroli A, Leone S, Ferrante C, Orlando G \& Vacca M 2011 Effects of vaspin, chemerin and omentin-1 on feeding behavior and hypothalamic peptide gene expression in the rat. Peptides 32 1866-1871. (https://doi. org/10.1016/j.peptides.2011.08.003)

Brunetti L, Orlando G, Ferrante C, Recinella L, Leone S, Chiavaroli A, Di Nisio C, Shohreh R, Manippa F, Ricciuti A,et al. 2014 Peripheral chemerin administration modulates hypothalamic control of feeding. Peptides 51 115-121. (https://doi.org/10.1016/j.peptides.2013.11.007)

Cash JL, Hart R, Russ A, Dixon JPC, Colledge WH, Doran J, Hendrick AG, Carlton MBL \& Greaves DR 2008 Synthetic chemerin-derived peptides suppress inflammation through ChemR23. Journal of Experimental Medicine 205 767-775. (https://doi.org/10.1084/jem.20071601)

Catrysse L \& van Loo G 2017 Inflammation and the metabolic syndrome: the tissue-specific functions of NF-kappaB. Trends in Cell Biology $\mathbf{2 7}$ 417-429. (https://doi.org/10.1016/j.tcb.2017.01.006)

Chakaroun R, Raschpichler M, Kloting N, Oberbach A, Flehmig G, Kern M, Schon MR, Shang E, Lohmann T, Dressler M,et al. 2012 Effects of weight loss and exercise on chemerin serum concentrations and adipose tissue expression in human obesity. Metabolism $\mathbf{6 1}$ 706-714. (https://doi.org/10.1016/j.metabol.2011.10.008)

Chang SS, Eisenberg D, Zhao L, Adams C, Leib R, Morser J \& Leung L 2016 Chemerin activation in human obesity. Obesity 24 1522-1529. (https://doi.org/10.1002/oby.21534)

Chiricozzi A, Raimondo A, Lembo S, Fausti F, Dini V, Costanzo A Monfrecola G, Balato N, Ayala F, Romanelli M,et al. 2016 Crosstalk between skin inflammation and adipose tissue-derived products: pathogenic evidence linking psoriasis to increased adiposity. Expert Review of Clinical Immunology 12 1299-1308. (https://doi.org/10.1080/ 1744666X.2016.1201423)

Coll AP \& Yeo GS 2013 The hypothalamus and metabolism: integrating signals to control energy and glucose homeostasis. Current Opinion in Pharmacology 13 970-976. (https://doi.org/10.1016/j. coph.2013.09.010)
Cutchins A, Harmon DB, Kirby JL, Doran AC, Oldham SN, Skaflen M, Klibanov AL, Meller N, Keller SR, Garmey J,et al. 2012 Inhibitor of differentiation-3 mediates high fat diet-induced visceral fat expansion. Arteriosclerosis, Thrombosis, and Vascular Biology 32 317-324. (https://doi.org/10.1161/ATVBAHA.111.234856)

De Henau O, Degroot GN, Imbault V, Robert V, De Poorter C, McHeik S, Gales C, Parmentier M \& Springael JY 2016 Signaling properties of chemerin receptors CMKLR1, GPR1 and CCRL2. PLOS ONE 11 e0164179. (https://doi.org/10.1371/journal.pone.0164179)

Deyama S, Shimoda K, Suzuki H, Ishikawa Y, Ishimura K, Fukuda H, Hitora-Imamura N, Ide S, Satoh M, Kaneda K,et al. 2018 Resolvin E1/ E2 ameliorate lipopolysaccharide-induced depression-like behaviors via ChemR23. Psychopharmacology 235 329-336. (https://doi. org/10.1007/s00213-017-4774-7)

DiSpirito JR \& Mathis D 2015 Immunological contributions to adipose tissue homeostasis. Seminars in Immunology 27 315-321. (https://doi. org/10.1016/j.smim.2015.10.005)

Ebling FJP 2014 On the value of seasonal mammals for identifying mechanisms underlying the control of food intake and body weight. Hormones and Behavior 66 56-65. (https://doi.org/10.1016/j. yhbeh.2014.03.009)

Edinger AL, Hoffman TL, Sharron M, Lee B, O'Dowd B \& Doms RW 1998 Use of GPR1, GPR15, and STRL33 as coreceptors by diverse human immunodeficiency virus type 1 and simian immunodeficiency virus envelope proteins. Virology 249 367-378. (https://doi.org/10.1006/ viro.1998.9306)

Ernst MC \& Sinal CJ 2010 Chemerin: at the crossroads of inflammation and obesity. Trends in Endocrinology and Metabolism 21 660-667. (https://doi.org/10.1016/j.tem.2010.08.001)

Ernst MC, Issa M, Goralski KB \& Sinal CJ 2010 Chemerin exacerbates glucose intolerance in mouse models of obesity and diabetes. Endocrinology 151 1998-2007. (https://doi.org/10.1210/en.2009-1098)

Ernst MC, Haidl ID, Zuniga LA, Dranse HJ, Rourke JL, Zabel BA, Butcher EC \& Sinal CJ 2012 Disruption of the chemokine-like receptor-1 (CMKLR1) gene is associated with reduced adiposity and glucose intolerance. Endocrinology 153 672-682. (https://doi. org/10.1210/en.2011-1490)

Esteghamati A, Ghasemiesfe M, Mousavizadeh M, Noshad S \& Nakhjavani M 2014 Pioglitazone and metformin are equally effective in reduction of chemerin in patients with type 2 diabetes. Journal of Diabetes Investigation 5 327-332. (https://doi.org/10.1111/jdi.12157)

Faramarzi M, Banitalebi E, Nori S, Farzin S \& Taghavian Z 2016 Effects of rhythmic aerobic exercise plus core stability training on serum omentin, chemerin and vaspin levels and insulin resistance of overweight women. Journal of Sports Medicine and Physical Finess 56 476-482.

Ferland DJ, Darios ES, Neubig RR, Sjogren B, Truong N, Torres R, Dexheimer TS, Thompson JM \& Watts SW 2017 Chemerininduced arterial contraction is Gi- and calcium-dependent. Vascular Pharmacology 88 30-41. (https://doi.org/10.1016/j.vph.2016.11.009)

Ghosh AR, Bhattacharya R, Bhattacharya S, Nargis T, Rahaman O, Duttagupta P, Raychaudhuri D, Liu CS, Roy S, Ghosh P,et al. 2016 Adipose recruitment and activation of plasmacytoid dendritic cells fuel metaflammation. Diabetes 65 3440-3452. (https://doi. org/10.2337/db16-0331)

Gonzalvo-Feo S, Del Prete A, Pruenster M, Salvi V, Wang L, Sironi M, Bierschenk S, Sperandio M, Vecchi A \& Sozzani S 2014 Endothelial cell-derived chemerin promotes dendritic cell transmigration. Journal of Immunology 192 2366-2373. (https://doi.org/10.4049/ jimmunol.1302028)

Goralski KB, McCarthy TC, Hanniman EA, Zabel BA, Butcher EC, Parlee SD, Muruganandan S \& Sinal CJ 2007 Chemerin, a novel adipokine that regulates adipogenesis and adipocyte metabolism. Journal of Biological Chemistry 282 28175-28188. (https://doi. org/10.1074/jbc.M700793200)
This work is licensed under a Creative Commons Attribution 4.0 Unported License.

ded from Bioscientifica com at 04/26/2023 10:58:23AM 
Gruben N, Aparicio Vergara M, Kloosterhuis NJ, van der Molen H, Stoelwinder S, Youssef S, de Bruin A, Delsing DJ, Kuivenhoven JA, van de Sluis B, et al. 2014 Chemokine-like receptor 1 deficiency does not affect the development of insulin resistance and nonalcoholic fatty liver disease in mice. PloS One 9 e96345.

Gu P, Jiang W, Lu B \& Shi Z 2014 Chemerin is associated with inflammatory markers and metabolic syndrome phenotypes in hypertension patients. Clinical and Experimental Hypertension 36 326-332. (https://doi.org/10.3109/10641963.2013.827697)

Guelfi KJ, Ong MJ, Li S, Wallman KE, Doherty DA, Fournier PA, Newnham JP \& Keelan JA 2017 Maternal circulating adipokine profile and insulin resistance in women at high risk of developing gestational diabetes mellitus. Metabolism 75 54-60. (https://doi.org/10.1016/j. metabol.2017.08.003)

Guo X, Fu Y, Xu Y, Weng S, Liu D, Cui D, Yu S, Liu X, Jiang K \& Dong Y 2012 Chronic mild restraint stress rats decreased CMKLR1 expression in distinct brain region. Neuroscience Letters $\mathbf{5 2 4}$ 25-29. (https://doi. org/10.1016/j.neulet.2012.06.075)

Hansen IR, Jansson KM, Cannon B \& Nedergaard J 2014 Contrasting effects of cold acclimation versus obesogenic diets on chemerin gene expression in brown and brite adipose tissues. Biochimica et Biophysica Acta 1841 1691-1699. (https://doi.org/10.1016/j. bbalip.2014.09.003)

Hare KJ, Bonde L, Svare JA, Randeva HS, Asmar M, Larsen S, Vilsbøll T \& Knop FK 2014 Decreased plasma chemerin levels in women with gestational diabetes mellitus. Diabetic Medicine 31 936-940. (https:// doi.org/10.1111/dme.12436)

Helfer G, Ross AW, Thomson LM, Mayer CD, Stoney PN, McCaffery PJ \& Morgan PJ 2016 A neuroendocrine role for chemerin in hypothalamic remodelling and photoperiodic control of energy balance. Scientific Reports 6 26830. (https://doi.org/10.1038/srep26830)

Huang C, Wang M, Ren L, Xiang L, Chen J, Li M, Xiao T, Ren P, Xiong L \& Zhang JV 2016 CMKLR1 deficiency influences glucose tolerance and thermogenesis in mice on high fat diet. Biochemical and Biophysical Research Communications 473 435-441. (https://doi. org/10.1016/j.bbrc.2016.03.026)

Inci S, Aksan G \& Doğan P 2016 Chemerin as an independent predictor of cardiovascular event risk. Therapeutic Advances in Endocrinology and Metabolism 7 57-68. (https://doi.org/10.1177/2042018816629894)

Jiang Y, Liu P, Jiao W, Meng J \& Feng J 2018 Gax suppresses chemerin/ CMKLR1-induced preadipocyte biofunctions through the inhibition of Akt/mTOR and ERK signaling pathways. Journal of Cellular Physiology 233 572-586. (https://doi.org/10.1002/jcp.25918)

Kaur J, Adya R, Tan BK, Chen J \& Randeva HS 2010 Identification of chemerin receptor (ChemR23) in human endothelial cells: chemerininduced endothelial angiogenesis. Biochemical and Biophysical Research Communications 391 1762-1768. (https://doi.org/10.1016/j. bbrc.2009.12.150)

Kennedy AJ \& Davenport AP 2018 International Union of Basic and clinical Pharmacology CIII: chemerin receptors CMKLR1 (Chemerin ${ }_{1}$ ) and GPR1 (Chemerin 2 ) nomenclature, pharmacology, and function. Pharmacological Reviews 70 174-196. (https://doi.org/10.1124/ pr.116.013177)

Kennedy AJ, Yang P, Read C, Kuc RE, Yang L, Taylor EJ, Taylor CW, Maguire JJ \& Davenport AP 2016 Chemerin elicits potent constrictor actions via chemokine-like receptor 1 (CMKLR1), not G-proteincoupled receptor 1 (GPR1), in human and rat vasculature. Journal of the American Heart Association 5 e004421. (https://doi.org/10.1161/ JAHA.116.004421)

Keophiphath M, Achard V, Henegar C, Rouault C, Clement K \& Lacasa D 2009 Macrophage-secreted factors promote a profibrotic phenotype in human preadipocytes. Molecular Endocrinology 23 11-24. (https://doi. org/10.1210/me.2008-0183)

Khoo J, Dhamodaran S, Chen D-D, Yap S-Y, Chen RY-T \& Tian RH-H 2015 Exercise-induced weight loss is more effective than dieting for improving adipokine profile, insulin resistance, and inflammation in obese men. International Journal of Sport Nutrition and Exercise Metabolism 25 566-575. (https://doi.org/10.1123/ijsnem.2015-0025)

Kim SM, Lun M, Wang M, Senyo SE, Guillermier C, Patwari P \& Steinhauser ML 2014 Loss of white adipose hyperplastic potential is associated with enhanced susceptibility to insulin resistance. Cell Metabolism 20 1049-1058. (https://doi.org/10.1016/j. cmet.2014.10.010)

Kim DI, Lee DH, Hong S, Jo SW, Won YS \& Jeon JY 2018 Six weeks of combined aerobic and resistance exercise using outdoor exercise machines improves fitness, insulin resistance, and chemerin in the Korean elderly: a pilot randomized controlled trial. Archives of Gerontology and Geriatrics 75 59-64. (https://doi.org/10.1016/j. archger.2017.11.006)

Kralisch S, Weise S, Sommer G, Lipfert J, Lossner U, Bluher M, Stumvoll M \& Fasshauer M 2009 Interleukin-1beta induces the novel adipokine chemerin in adipocytes in vitro. Regulatory Peptides 154 102-106. (https://doi.org/10.1016/j.regpep.2009.02.010)

Kunimoto H, Kazama K, Takai M, Oda M, Okada M \& Yamawaki H 2015 Chemerin promotes the proliferation and migration of vascular smooth muscle and increases mouse blood pressure. American Journal of Physiology: Heart and Circulatory Physiology 309 H1017-H1028. (https://doi.org/10.1152/ajpheart.00820.2014)

Landgraf K, Friebe D, Ullrich T, Kratzsch J, Dittrich K, Herberth G, Adams V, Kiess W, Erbs S \& Korner A 2012 Chemerin as a mediator between obesity and vascular inflammation in children. Journal of Clinical Endocrinology and Metabolism 97 E556-E564. (https://doi. org/10.1210/jc.2011-2937)

Lee YH, Petkova AP \& Granneman JG 2013 Identification of an adipogenic niche for adipose tissue remodeling and restoration. Cell Metabolism 18 355-367. (https://doi.org/10.1016/j.cmet.2013.08.003)

Lehr S, Hartwig S \& Sell H 2012 Adipokines: a treasure trove for the discovery of biomarkers for metabolic disorders. Proteomics: Clinical Applications 6 91-101.

Li L, Ma P, Huang C, Liu Y, Zhang Y, Gao C, Xiao T, Ren PG, Zabel BA \& Zhang JV 2014 Expression of chemerin and its receptors in rat testes and its action on testosterone secretion. Journal of Endocrinology $\mathbf{2 2 0}$ 155-163. (https://doi.org/10.1530/JOE-13-0275)

Li HX, Chen KL, Wang HY, Tang CB, Xu XL \& Zhou GH 2015 Chemerin inhibition of myogenesis and induction of adipogenesis in $\mathrm{C} 2 \mathrm{C} 12$ myoblasts. Molecular and Cellular Endocrinology 414 216-223. (https:// doi.org/10.1016/j.mce.2015.07.006)

Lijnen HR 2008 Angiogenesis and obesity. Cardiovascular Research $\mathbf{7 8}$ 286-293. (https://doi.org/10.1093/cvr/cvm007)

Lin S, Teng J, Li J, Sun F, Yuan D \& Chang J 2016 Association of chemerin and vascular endothelial growth factor (VEGF) with diabetic nephropathy. Medical Science Monitor 22 3209-3214. (https://doi. org/10.12659/MSM.896781)

Liu L \& Meydani M 2003 Angiogenesis inhibitors may regulate adiposity. Nutrition Reviews 61 384-387. (https://doi.org/10.1301/nr.2003. nov.384-387)

Luangsay S, Wittamer V, Bondue B, De Henau O, Rouger L, Brait M, Franssen JD, de Nadai P, Huaux F \& Parmentier M 2009 Mouse ChemR23 is expressed in dendritic cell subsets and macrophages, and mediates an anti-inflammatory activity of chemerin in a lung disease model. Journal of Immunology 183 6489-6499. (https://doi. org/10.4049/jimmunol.0901037)

Martensson UEA, Bristulf J, Owman C \& Olde B 2005 The mouse chemerin receptor gene, mcmklr1, utilizes alternative promoters for transcription and is regulated by all-trans retinoic acid. Gene $\mathbf{3 5 0}$ 65-77. (https://doi.org/10.1016/j.gene.2005.02.004)

Mattern A, Zellmann T \& Beck-Sickinger AG 2014 Processing, signaling, and physiological function of chemerin. IUBMB Life 66 19-26. (https://doi.org/10.1002/iub.1242)

Meder W, Wendland M, Busmann A, Kutzleb C, Spodsberg N, John H, Richter R, Schleuder D, Meyer M \& Forssmann WG 2003 Characterization of human circulating TIG2 as a ligand for the

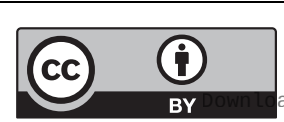

This work is licensed under a Creative Commons Attribution 4.0 Unported License. Ated from Bioscientifica com at 04/26/2023 10:58:23AM 
orphan receptor ChemR23. FEBS Letters 555 495-499. (https://doi. org/10.1016/S0014-5793(03)01312-7)

Miranda-Angulo AL, Byerly MS, Mesa J, Wang H \& Blackshaw S 2014 Rax regulates hypothalamic tanycyte differentiation and barrier function in mice. Journal of Comparative Neurology 522 876-899. (https://doi. org/10.1002/cne.23451)

Mraz M \& Haluzik M 2014 The role of adipose tissue immune cells in obesity and low-grade inflammation. Journal of Endocrinology 222 R113-127. (https://doi.org/10.1530/JOE-14-0283)

Muruganandan S, Parlee SD, Rourke JL, Ernst MC, Goralski KB \& Sinal CJ 2011 Chemerin, a novel peroxisome proliferator-activated receptor gamma (PPARgamma) target gene that promotes mesenchymal stem cell adipogenesis. Journal of Biological Chemistry 286 23982-23995. (https://doi.org/10.1074/jbc.M111.220491)

Muruganandan S, Govindarajan R, McMullen NM \& Sinal CJ 2017 Chemokine-like receptor 1 is a novel Wnt target gene that regulates mesenchymal stem cell differentiation. Stem Cells 35 711-724. (https://doi.org/10.1002/stem.2520)

Nagpal S, Patel S, Jacobe H, DiSepio D, Ghosn C, Malhotra M, Teng M, Duvic M \& Chandraratna RA 1997 Tazarotene-induced gene 2 (TIG2), a novel retinoid-responsive gene in skin. Journal of Investigative Dermatology 109 91-95. (https://doi.org/10.1111/1523-1747. ep12276660)

Neves KB, Nguyen Dinh Cat A, Lopes RA, Rios FJ, Anagnostopoulou A, Lobato NS, de Oliveira AM, Tostes RC, Montezano AC \& Touyz RM 2015 Chemerin regulates crosstalk between adipocytes and vascular cells through Nox. Hypertension 66 657-666.

Okla M, Kim J, Koehler K \& Chung S 2017 Dietary factors promoting brown and beige fat development and thermogenesis. Advances in Nutrition 8 473-483. (https://doi.org/10.3945/an.116.014332)

Parolini S, Santoro A, Marcenaro E, Luini W, Massardi L, Facchetti F, Communi D, Parmentier M, Majorana A, Sironi M,et al. 2007 The role of chemerin in the colocalization of NK and dendritic cell subsets into inflamed tissues. Blood 109 3625-3632. (https://doi.org/10.1182/ blood-2006-08-038844)

Peng L, Yu Y, Liu J, Li S, He H, Cheng N \& Ye RD 2015 The chemerin receptor CMKLR1 is a functional receptor for amyloid-beta peptide. Journal of Alzheimer's Disease 43 227-242. (https://doi.org/10.3233/ Jad-141227)

Perumalsamy S, Aqilah Mohd Zin NA, Widodo RT, Wan Ahmad WA, Vethakkan S \& Huri HZ 2017 Chemokine like receptor-1 (CMKLR-1) receptor: a potential therapeutic target in management of chemerin induced type 2 diabetes mellitus and cancer. Current Pharmaceutical Design 23 3689-3698. (https://doi.org/10.2174/13816128236661706 16081256)

Reverchon M, Cornuau M, Ramé C, Guerif F, Royère D \& Dupont J 2012 Chemerin inhibits IGF-1-induced progesterone and estradiol secretion in human granulosa cells. Human Reproduction 27 1790-1800. (https://doi.org/10.1093/humrep/des089)

Roh SG, Song SH, Choi KC, Katoh K, Wittamer V, Parmentier M \& Sasaki S 2007 Chemerin - a new adipokine that modulates adipogenesis via its own receptor. Biochemical and Biophysical Research Communications 362 1013-1018. (https://doi.org/10.1016/j. bbrc.2007.08.104)

Roman AA, Parlee SD \& Sinal CJ 2012 Chemerin: a potential endocrine link between obesity and type 2 diabetes. Endocrine 42 243-251. (https://doi.org/10.1007/s12020-012-9698-8)

Ross AW, Helfer G, Russell L, Darras VM \& Morgan PJ 2011 Thyroid hormone signalling genes are regulated by photoperiod in the hypothalamus of F344 rats. PLOS ONE 6 e21351. (https://doi. org/10.1371/journal.pone.0021351)

Rouger L, Denis GR, Luangsay S \& Parmentier M 2013 ChemR23 knockout mice display mild obesity but no deficit in adipocyte differentiation. Journal of Endocrinology 219 279-289. (https://doi. org/10.1530/JOE-13-0106)
Rourke JL, Dranse HJ \& Sinal CJ 2013 Towards an integrative approach to understanding the role of chemerin in human health and disease. Obesity Reviews 14 245-262. (https://doi.org/10.1111/obr.12009)

Rourke JL, Muruganandan S, Dranse HJ, McMullen NM \& Sinal CJ 2014 Gpr1 is an active chemerin receptor influencing glucose homeostasis in obese mice. Journal of Endocrinology 222 201-215. (https://doi. org/10.1530/JOE-14-0069)

Rourke JL, Dranse HJ \& Sinal CJ 2015 CMKLR1 and GPR1 mediate chemerin signaling through the RhoA/ROCK pathway. Molecular and Cellular Endocrinology 417 36-51. (https://doi.org/10.1016/j. mce.2015.09.002)

Rupnick MA, Panigrahy D, Zhang CY, Dallabrida SM, Lowell BB, Langer R \& Folkman MJ 2002 Adipose tissue mass can be regulated through the vasculature. PNAS 99 10730-10735. (https://doi.org/10.1073/ pnas.162349799)

Samson M, Edinger AL, Stordeur P, Rucker J, Verhasselt V, Sharron M, Govaerts C, Mollereau C, Vassart G \& Doms RW 1998 ChemR23, a putative chemoattractant receptor, is expressed in monocyte-derived dendritic cells and macrophages and is a coreceptor for SIV and some primary HIV-1 strains. European Journal of Immunology 28 1689-1700. (https://doi.org/10.1002/(SICI)1521-4141(199805)28:05<1689::AIDIMMU1689>3.0.CO;2-I)

Sell H, Laurencikiene J, Taube A, Eckardt K, Cramer A, Horrighs A, Arner P \& Eckel J 2009 Chemerin is a novel adipocyte-derived factor inducing insulin resistance in primary human skeletal muscle cells. Diabetes $\mathbf{5 8}$ 2731-2740. (https://doi.org/10.2337/db09-0277)

Sell H, Divoux A, Poitou C, Basdevant A, Bouillot JL, Bedossa P, Tordjman J, Eckel J \& Clement K 2010 Chemerin correlates with markers for fatty liver in morbidly obese patients and strongly decreases after weight loss induced by bariatric surgery. Journal of Clinical Endocrinology and Metabolism 95 2892-2896. (https://doi. org/10.1210/jc.2009-2374)

Shimizu N, Soda Y, Kanbe K, Liu H-Y, Jinno A, Kitamura T \& Hoshino H 1999 An orphan G protein-coupled receptor, GPR1, acts as a coreceptor to allow replication of human immunodeficiency virus types 1 and 2 in brain-derived cells. Journal of Virology 73 5231-5239.

Shin HY, Lee DC, Chu SH, Jeon JY, Lee MK, Im JA \& Lee JW 2012 Chemerin levels are positively correlated with abdominal visceral fat accumulation. Clinical Endocrinology 77 47-50. (https://doi. org/10.1111/j.1365-2265.2011.04217.x)

Southern C, Cook JM, Neetoo-Isseljee Z, Taylor DL, Kettleborough CA, Merritt A, Bassoni DL, Raab WJ, Quinn E, Wehrman TS, et al. 2013 Screening beta-arrestin recruitment for the identification of natural ligands for orphan G-protein-coupled receptors. Journal of Biomolecular Screening 18 599-609. (https://doi.org/10.1177/1087057113475480)

Stelmanska E, Sledzinski T, Turyn J, Presler M, Korczynska J \& Swierczynski J 2013 Chemerin gene expression is regulated by food restriction and food restriction-refeeding in rat adipose tissue but not in liver. Regulatory Peptides 181 22-29. (https://doi.org/10.1016/j. regpep.2012.12.001)

Sun K, Kusminski CM \& Scherer PE 2011 Adipose tissue remodeling and obesity. Journal of Clinical Investigation 121 2094-2101. (https://doi. org/10.1172/JCI45887)

Takahashi M, Takahashi Y, Takahashi K, Zolotaryov FN, Hong KS, Kitazawa R, Iida K, Okimura Y, Kaji H, Kitazawa S, et al. 2008 Chemerin enhances insulin signaling and potentiates insulinstimulated glucose uptake in 3T3-L1 adipocytes. FEBS Letters $\mathbf{5 8 2}$ 573-578. (https://doi.org/10.1016/j.febslet.2008.01.023)

Takahashi M, Okimura Y, Iguchi G, Nishizawa H, Yamamoto M, Suda K, Kitazawa R, Fujimoto W, Takahashi K, Zolotaryov FN,et al. 2011 Chemerin regulates $\beta$-cell function in mice. Scientific Reports 1123. (https://doi.org/10.1038/srep00123)

Takahashi M, Inomata S, Okimura Y, Iguchi G, Fukuoka H, Miyake K, Koga D, Akamatsu S, Kasuga M \& Takahashi Y 2013 Decreased serum chemerin levels in male Japanese patients with type 2 diabetes: sex http://joe.endocrinology-journals.org

https://doi.org/10.1530/JOE-18-0174 (c) 2018 The authors Published by Bioscientifica Ltd. Printed in Great Britain

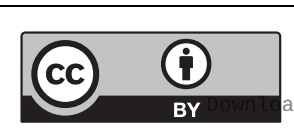

This work is licensed under a Creative Common Attribution 4.0 Unported License.

Aed from Bioscientifica com at 04/26/2023 10:58:23AM 
dimorphism. Endocrine Journal 60 37-44. (https://doi.org/10.1507/ endocrj.EJ12-0201)

Tam CS, Clement K, Baur LA \& Tordjman J 2010 Obesity and low-grade inflammation: a paediatric perspective. Obesity Reviews 11 118-126. (https://doi.org/10.1111/j.1467-789X.2009.00674.x)

Tavolaro FM, Thomson LM, Ross AW, Morgan PJ \& Helfer G 2015 Photoperiodic effects on seasonal physiology, reproductive status and hypothalamic gene expression in young male F344 rats. Journal of Neuroendocrinology 27 79-87. (https://doi.org/10.1111/jne.12241)

Thedrez A, Scharfmann R, Parnet P, Nobecourt E \& Lambert G 2016 Lipoproteins and lipid metabolism: lipoprotein metabolism. LDL receptor (LDLR) expression and function in human pancreatic beta cells. Atherosclerosis 252 E115-E116. (https://doi.org/10.1016/j. atherosclerosis.2016.07.622)

Uehata M, Ishizaki T, Satoh H, Ono T, Kawahara T, Morishita T, Tamakawa H, Yamagami K, Inui J, Maekawa M, et al. 1997 Calcium sensitization of smooth muscle mediated by a Rho-associated protein kinase in hypertension. Nature 389 990-994.

Vermi W, Riboldi E, Wittamer V, Gentili F, Luini W, Marrelli S, Vecchi A, Franssen JD, Communi D, Massardi L,et al. 2005 Role of ChemR23 in directing the migration of myeloid and plasmacytoid dendritic cells to lymphoid organs and inflamed skin. Journal of Experimental Medicine 201 509-515. (https://doi.org/10.1084/jem.20041310)

Wang N, Wang QJ, Feng YY, Shang W \& Cai M 2014 Overexpression of chemerin was associated with tumor angiogenesis and poor clinical outcome in squamous cell carcinoma of the oral tongue. Clinical Oral Investigations 18 997-1004. (https://doi.org/10.1007/s00784-0131046-8)

Wargent ET, Zaibi MS, O'Dowd JF, Cawthorne MA, Wang SJ, Arch JR \& Stocker CJ 2015 Evidence from studies in rodents and in isolated adipocytes that agonists of the chemerin receptor CMKLR1 may be beneficial in the treatment of type 2 diabetes. PeerJ 3 e753. (https:// doi.org/10.7717/peerj.753)

Weigert J, Neumeier M, Wanninger J, Filarsky M, Bauer S, Wiest R, Farkas S, Scherer MN, Schaffler A, Aslanidis C,et al. 2010 Systemic chemerin is related to inflammation rather than obesity in type 2 diabetes. Clinical Endocrinology 72 342-348. (https://doi.org/10.1111/ j.1365-2265.2009.03664.x)

Weisberg SP, McCann D, Desai M, Rosenbaum M, Leibel RL \& Ferrante AW Jr 2003 Obesity is associated with macrophage accumulation in adipose tissue. Journal of Clinical Investigation 112 1796-1808. (https://doi.org/10.1172/JCI200319246)
Wittamer V, Franssen JD, Vulcano M, Mirjolet JF, Le Poul E, Migeotte I, Brezillon S, Tyldesley R, Blanpain C, Detheux M,et al. 2003 Specific recruitment of antigen-presenting cells by chemerin, a novel processed ligand from human inflammatory fluids. Journal of Experimental Medicine 198 977-985. (https://doi.org/10.1084/ jem.20030382)

Wittamer V, Bondue B, Guillabert A, Vassart G, Parmentier M \& Communi D 2005 Neutrophil-mediated maturation of chemerin: a link between innate and adaptive immunity. Journal of Immunology 175 487-493. (https://doi.org/10.4049/jimmunol.175.1.487)

Yang M, Yang G, Dong J, Liu Y, Zong H, Liu H, Boden G \& Li L 2010 Elevated plasma levels of chemerin in newly diagnosed type 2 diabetes mellitus with hypertension. Journal of Investigative Medicine 58 883-886. (https://doi.org/10.2310/JIM.0b013e3181ec5db2)

Yang X, Quan X, Lan Y, Ye J, Wei Q, Yin X, Fan F \& Xing H 2017 Serum chemerin level during the first trimester of pregnancy and the risk of gestational diabetes mellitus. Gynecological Endocrinology 33 770-773. (https://doi.org/10.1080/09513590.2017.1320382)

Zabel BA, Silverio AM \& Butcher EC 2005 Chemokine-like receptor 1 expression and chemerin-directed chemotaxis distinguish plasmacytoid from myeloid dendritic cells in human blood. Journal of Immunology 174 244-251. (https://doi.org/10.4049/ jimmunol.174.1.244)

Zabel BA, Ohyama T, Zuniga L, Kim JY, Johnston B, Allen SJ, Guido DG, Handel TM \& Butcher EC 2006 Chemokine-like receptor 1 expression by macrophages in vivo: regulation by TGF-beta and TLR ligands. Experimental Hematology 34 1106-1114. (https://doi.org/10.1016/j. exphem.2006.03.011)

Zabel BA, Nakae S, Zuniga L, Kim JY, Ohyama T, Alt C, Pan J, Suto H, Soler D, Allen SJ,et al. 2008 Mast cell-expressed orphan receptor CCRL2 binds chemerin and is required for optimal induction of IgE-mediated passive cutaneous anaphylaxis. Journal of Experimental Medicine 205 2207-2220. (https://doi.org/10.1084/ jem.20080300)

Zhang L, Pan J, Dong Y, Tweardy DJ, Dong Y, Garibotto G \& Mitch WE 2013 Stat3 activation links a C/EBPdelta to myostatin pathway to stimulate loss of muscle mass. Cell Metabolism 18 368-379. (https:// doi.org/10.1016/j.cmet.2013.07.012)

Zhao L, Yamaguchi Y, Sharif S, Du XY, Song JJ, Lee DM, Recht LD, Robinson WH, Morser J \& Leung LL 2011 Chemerin158K protein is the dominant chemerin isoform in synovial and cerebrospinal fluids but not in plasma. Journal of Biological Chemistry 286 39520-39527.

Received in final form 9 May 2018

Accepted 30 May 2018

Accepted Preprint published online 30 May 2018

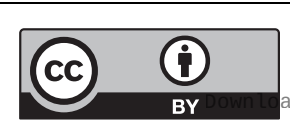

This work is licensed under a Creative Commons Attribution 4.0 Unported License. 